\title{
Reproduction in the Yellow-spotted night lizard, Lepidophyma flavimaculatum (Squamata, Xantusiidae), from Costa Rica
}

\author{
Stephen R. Goldberg \\ Department of Biology, Whittier College, PO Box 634, Whittier, California 90608, USA - E-mail: sgoldberg@whittier.edu.
}

Keywords: Squamata, Xantusiidae, Lepidophyma flavimaculatum, reproduction, Costa Rica.

Palavras-chave: Squamata, Xantusiidae, Lepidophyma flavimaculatum, reprodução, Costa Rica.

Lepidophyma flavimaculatum Duméril, 1851 is a secretive inhabitant of undisturbed moist and wet forests, typically found under fallen logs in the humid lowlands from Oaxaca and southern Veracruz, Mexico to central Panama (Savage 2002). Like other xantusiids $L$. flavimaculatum is viviparous (Goin et al. 1978). Telford and Campbell (1970) reported that $L$. flavimaculatum populations from central Panama were all-female, however, Bezy (1989) concluded that $L$. flavimaculatum populations from Honduras and northward included $41 \%$ (30/73) males and were probably bisexual. The purpose of this note is to add information on reproduction of L. flavimaculatum from a histological examination of gonadal material from museum specimens from five Provinces of Costa Rica. The first information on the testicular cycle is presented. Minimum sizes for reproduction of males and females are given.

Received 7 April 2009.

Accepted 15 May 2009.

Distributed July 2009.
A total of 60 L. flavimaculatum from Costa Rica including 26 adult females (mean snout vent length, SVL $=85.0 \mathrm{~mm} \pm 6.6 \mathrm{SD}$, range $=73-96$; six adult males, mean SVL $=87.5 \mathrm{~mm} \pm 7.4 S D$, range $=77-98 \mathrm{~mm}$; 13 juveniles, mean $\mathrm{SVL}=63.5 \pm 4.0 \mathrm{SD}$. range $=58-71 \mathrm{~mm}$ and 15 neonates, mean SVL $=36.3$ $\mathrm{mm} \pm 3.0 S D$, range $=30-39 \mathrm{~mm}$ ) were examined from the herpetology collection of the Natural History Museum of Los Angeles County (LACM), Los Angeles, California (Appendix I). Lizards were collected 1961 to 1992.

The left testis was removed from males and the left ovary was removed from females for histological examination. Enlarged follicles (> $4 \mathrm{~mm}$ length) were counted. Tissues were embedded in paraffin and cut into sections of $5 \mu \mathrm{m}$. Slides were stained with Harris hematoxylin followed by eosin counterstain (Presnell and Schreibman 1997). Slides of testes were examined to determine the stage of the spermatogenic cycle. Slides of ovaries were examined for the presence of yolk deposition or corpora lutea. Histology slides were deposited in LACM. An unpaired $t$-test was used to 
compare L. flavimaculatum male and female mean body sizes and chi-square test was used to compare ratios of males versus females (Instat, vers. 3.0b, Graphpad Software, San Diego, CA).

No significant size difference was detected between L. flavimaculatum males and females (unpaired $t$-test, $t=0.82, d f=30, P=0.42$ ). Two stages were present in the testicular cycle of $L$. flavimaculatum (Table 1). (1) Recrudescence: occurs prior to the onset of spermiogenesis (sperm formation). Secondary spermatocytes and spermatocytes are the predominant cells; (2) Spermiogenesis in which the seminiferous tubules are lined by clusters of spermatozoa and/or metamorphosing spermatids. The smallest reproductively active male (in recrudescence) measured $77 \mathrm{~mm} \mathrm{SVL}$ (LACM 131097) and was from August. My samples are too small to completely elucidate the seasonal testicular cycle of L. flavimaculatum as one each spermiogenic male came from Limón and Heredia Provinces, nevertheless these preliminary data indicated a late-summer to autumn period of sperm formation. This appears similar to the timing of the testicular cycles of other species of Lepidophyma: L. gaigae (Goldberg and Camarillo-Rangel 2003), L. sylvaticum (Ramírez-Hernández 2003, RamírezBautista et al. 2008) and L. pajapanensis (Méndez-de La Cruz et al. 1999) in which males are reproductively active in summer to autumn. It thus appears from my results and other studies on congeneric species that Lepidophyma males undergo a late-summer to autumn period of sperm formation This timing differs from males of the xantusiid lizards, Xantusia vigilis (Zweifel and Lowe 1966) a desert species, and Xantusia riversiana (Goldberg and Bezy 1974), an island species in which mating occurs in spring.

Yolk deposition in L. flavimaculatum commences in spring and continues into late summer (Table 2) when males are producing sperm. Twelve of the August females in Table 2 were from the same locality, Hacienda
Table 1 - Monthly stages in the testicular cycle of six Lepidophyma flavimaculatum from Costa Rica.

\begin{tabular}{lccc}
\hline Month & $n$ & Recrudescent & Spermiogenesis \\
\hline June & 1 & 1 & 0 \\
July & 1 & 1 & 0 \\
August & 3 & 2 & 1 \\
October & 1 & 0 & 1 \\
\hline
\end{tabular}

Tapezco, $29 \mathrm{~km} \mathrm{~W}$ Tortugero in Límon Province. Seven of these exhibited quiescent ovaries with no yolk deposition. Five were in early yolk deposition. One female (LACM 159177) from Heredia Province collected in January contained 4 enlarged follicles $>5 \mathrm{~mm}$ diameter suggesting young would have been produced late that spring. This is the only clutch I can report. Lepidophyma flavimaculatum from Panama produce 4-8 young that measure 35-38 mm SVL (Telford and Campbell 1970, Alvarez del Toro 1982). This is in agreement with Telford and Campbell (1970) who reported $L$. flavimaculatum in Panama are born in late April-early June around the start of the wet season and June or July in Chiapas, Mexico (Alvarez del Toro 1982). This occurs in other species of Lepidophyma which also produce young in spring (L. tuxtlae Castillo-Cerón and López-González, 1990; L. lowei Camarillo R., 1999; L. sylvaticum Ramírez-Hernández, 2003; L. gaigae Goldberg and Camarillo-Rangel, 2003). The smallest reproductively active females of L. flavimaculatum (both in early yolk deposition) measured $79 \mathrm{~mm}$ SVL (LACM 128547, 131092) and were from September and August, respectively. In Costa Rica, lizards of neonate size were collected in May to September.

The sex ratio of six adult males and 26 adult females was significantly different from the expected 50:50 ratio (chi squared $=12.5, d f=$ $1, P=0.0004)$. This may suggest that at least some of the L. flavimaculatum females from Costa Rica are parthenogenetic. My findings of 
Table 2 - Monthly stages in the ovarian cycle of 26 Lepidophyma flavimaculatum from Costa Rica.

\begin{tabular}{lcccc}
\hline Month & $n$ & No yolk deposition & Early yolk deposition & Follicles $>4 \mathrm{~mm}$ \\
\hline January & 2 & 1 & 0 & 1 \\
March & 1 & 1 & 0 & 0 \\
April & 1 & 1 & 0 & 0 \\
May & 4 & 3 & 1 & 0 \\
July-August & 1 & 0 & 1 & 0 \\
August & 12 & 7 & 5 & 0 \\
September & 5 & 4 & 1 & 0 \\
\hline
\end{tabular}

a reduced frequency of males in Costa Rica suggests either a patchwork of parthenogenetic and sexual populations or replacement of sexual populations by parthenogentic populations. Similar sex ratio bias toward females has been reported for L. flavimaculatum in Panama (Telford and Campbell 1970), L. reticulatum (Bezy 1989) and L. tuxtlae from Veracruz, Mexico (Castillo-Cerón and López González 1990).

The presence of $15 / 23(65 \%)$ nonreproductive females (no yolk deposition) of adult size (May-September) during which time other L. flavimaculatum females are depositing yolk indicates only a portion of the female population reproduces each year. This was also reported in $X$. riversiana (Goldberg and Bezy 1974) and also occurs in Xenosaurus grandis in Mexico (Ballinger et al. 2000), but is more typical of lizards living in very harsh environments (Cree and Guillette Jr. 1995, Boretto and Ibargüengoytía 2006, Ibargüengoytia and Casalins 2007).

Utilization of museum specimens to gather reproductive data is becoming increasingly important as it is very difficult to obtain permission to collect monthly samples of native populations from the same locality. This is particularly true for secretive species like $L$. flavimaculatum, collection of which, results in habitat destruction. Also, localized variations in the reproductive cycle will likely not be detected from examination of museum specimens since the investigator must work with available materials.

In summary, L. flavimaculatum in Costa Rica may consist of a mixture of sexually reproducing and parthenogenetic populations (based on female-biased sex ratios), mating occurs in late summer, females produce live young in late spring at the beginning of the wet season, and only a portion of females produce offspring in a given year. This reproductive cycle is similar to that in other tropical xantusiids.

\section{Acknowledgements}

I thank Christine Thacker (LACM) for permission to examine specimens. Some $L$. flavimaculatum are part of the CRE (= Costa Rica Expeditions) collection donated to LACM by Jay M. Savage in 1998 .

\section{References}

Alvarez del Toro, M. 1982. Los Reptiles de Chiapas. Tercera Edic. Publicación del Instituto de Historia Natural, Tuxtla Gutierrez, Chiapas, Mexico. 248 pp.

Ballinger, R. E., J. A. Lemos-Espinal and G. R. Smith. 2000. Reproduction in females of three species of crevice-dwelling lizards (genus Xenosaurus) from Mexico. Studies on Neotropical Fauna and Environment 35: 179-183. 
Bezy, R. L. 1989. Morphological differentiation in unisexual and bisexual xantusiid lizards of the genus Lepidophyma in Central America. Herpetological Monographs 3: 61-80.

Boretto, J. M. and N. R. Ibargüengoytía. 2006. Asynchronous spermatogenesis and biennial female cycle of the viviparous lizard Phymaturus antofagastensis (Liolaemidae): reproductive responses to high altitudes and temperate climate of Catamarca, Argentina. Amphibia-Reptilia 27: 25-36.

Camarillo R., J. R. 1999. Lepidophyma lowei (Lowe's Tropical Night Lizard). Reproduction. Herpetological Review 30: 97.

Castillo-Cerón, J. M. and C. A. López González. 1990. Notes on the biology and status of a population of Lepidophyma tuxtlae (Sauria: Xantusiidae) in the Sierra de Santa Marta, Veracruz, México. Bulletin of the Maryland Herpetological Society 26: 153-158.

Cree, A. and L. J. Guillette Jr. 1995. Biennial reproduction with a fourteen-month pregnancy in the gecko Hoplodactylus maculatus from southern New Zealand. Journal of Herpetology 29: 163-173.

Goin, C. J., O. B. Goin and G. R. Zug. 1978. Introduction to Herpetology, $3^{\text {rd }}$ Ed. New York. W. H. Freeman Co. $378 \mathrm{pp}$.

Goldberg, S. R. and R. L. Bezy. 1974. Reproduction in the island night lizard, Xantusia riversiana. Herpetologica 30: $350-360$.

Goldberg, S. R. and J. L. Camarillo-Rangel. 2003. Lepidophyma gaigae (Gaige's Tropical Night Lizard). Reproduction. Herpetological Review 34: 246.

Ibargüengoytía, N. R. and L. M. Casalins. 2007. Reproductive biology of the southernmost gecko
Homonota darwini: convergent life-history patterns among Southern Hemisphere reptiles living in harsh environments. Journal of Herpetology 41: 72-80.

Méndez-de La Cruz, F. R., M. Villagrán-Santa Cruz, O. Hernández-Gallegos, N. L. Manríquez-Morán, and F. J. Rodríguez-Romero. 1999. Reproductive cycle of the tropical night lizard Lepidophyma pajapanensis from Veracruz, México. Journal of Herpetology 33: 336339.

Presnell, J. K. and M. P. Schreibman. 1997. Humason's Animal Tissue Techniques. $5^{\text {th }}$ Ed. Baltimore. The Johns Hopkins University Press. 572 pp.

Ramírez-Bautista, A., L. J. Vitt, A. Ramírez-Hernández, F. Mendoza Quijano, and G. R. Smith. 2008. Reproduction and sexual dimorphism of Lepidophyma sylvaticum (Squamata; Xantusiidae), a tropical night lizard from Tlanchinol, Hidalgo, Mexico. AmphibiaReptilia 29: 207-216.

Ramírez-Hernández, A. R. 2003. Ciclo reproductivo de la lagartija vivipara de montaña Lepidophyma sylvaticum (Sauria: Xantusiidae) de Tlanchinol, Hidalgo. Boletin de la Sociedad Herpetologica Mexicana 11: 23-24.

Savage, J. M. 2002. The Amphibians of Costa Rica: a herpetofauna between two continents, between two seas. Chicago. The University of Chicago Press. 934 pp.

Telford, S. R., Jr. and H. W. Campbell. 1970. Ecological observations on an all female population of the lizard Lepidophyma flavimaculatum (Xantusiidae) in Panama. Copeia 1970: 379-381.

Zweifel, R. G. and C. H. Lowe. 1966. The ecology of a population of Xantusia vigilis, the desert night lizard. American Museum Novitates 2247: 1-57.

\section{Appendix I - Lepidophyma flavimaculatum from Costa Rica (by province) examined from the herpetology collection of LACM.}

Alajuela: 114858, Guanacaste: 137449 , 159156, Heredia: 128538, 128539, 128541, $128547,128549,128555,128556,128558$, 159146, 159150, 159152, 159155, 159158, 159159, 159168, 159177, 159179-159181,
Limón: 131086-131088, 131092-131102, 131104, 131108-131111, 132392, 159153, 159161, 159163, 159164, Puntarenas: 72323, 76161-76169, 106794, 159140159142 . 